\title{
Comparison of the Photosynthetic Capacity of Phragmites australis in Five Habitats in Saline-Alkaline Wetlands
}

\author{
Subang An ${ }^{1,2}$, Xingtu Liu ${ }^{1,2, *}$, Bolong Wen ${ }^{1}$, Xiaoyu Li ${ }^{1} \mathbb{D}$, Peng Qi ${ }^{1}$ and Kun Zhang ${ }^{3}$ \\ 1 Key Laboratory of Wetland Ecology and Environment, Northeast Institute of Geography and Agroecology, \\ Chinese Academy of Sciences, Changchun 130102, China; ansubang@iga.ac.cn (S.A.); \\ wenbolong@iga.ac.cn (B.W.); lixiaoyu@iga.ac.cn (X.L.); qipeng@iga.ac.cn (P.Q.) \\ 2 University of Chinese Academy of Sciences, Beijing 100049, China \\ 3 College of Wetland Science, Southwest Forestry University, Kunming 650224, China; zhangkun@swfu.edu.cn \\ * Correspondence: liuxingtu@iga.ac.cn; Tel.: +86-136-7430-4616
}

Received: 15 August 2020; Accepted: 5 October 2020; Published: 6 October 2020

\begin{abstract}
Water shortages have an important impact on the photosynthetic capacity of Phragmites australis. However, this impact has not been adequately studied from the perspective of photosynthesis. An in-depth study of the photosynthetic process can help in better understanding the impact of water shortages on the photosynthetic capacity of $P$. australis, especially on the microscale. The aim of this study is to explore the photosynthetic adaptation strategies to environmental changes in saline-alkaline wetlands. The light response curves and $\mathrm{CO}_{2}$ response curves of P. australis in five habitats (hygrophilous, xerophytic, psammophytic, abandoned farmland, paddy field drainage) in saline-alkaline wetlands were measured at different stages of their life history, and we used a nonrectangular hyperbolic model to fit the data. It was concluded that $P$. australis utilized coping strategies that differed between the growing and breeding seasons. P. australis in abandoned farmland during the growing season had the highest apparent quantum efficiency (AQE) and photosynthetic utilization efficiency for weak light because of the dark environment. The dark respiration rate of $P$. australis in the drainage area of paddy fields was the lowest, and it had the highest values for photorespiration rate, maximum photosynthetic rate (Pmax), photosynthetic capacity (Pa), biomass, maximum carboxylation rate (Vcmax), and maximum electron transfer rate (Jmax). The light insensitivity of $P$. australis increased with the transition from growing to breeding season, and the dark respiration rate also showed a downward trend. Moreover, Vcmax and Jmax would decline when Pmax and Pa showed a declining trend, and vice versa. In other words, Vcmax and Jmax could explain changes in the photosynthetic capacity to some extent. These findings contribute to providing insights that $\mathrm{V}$ cmax and Jmax can directly reflect the variation in photosynthetic capacity of $P$. australis under water shortages in saline-alkaline wetlands and in other parts of world where there are problems with similarly harmful environmental conditions.
\end{abstract}

Keywords: Amur River Basin; Heilongjiang Province; Jilin Province; Phragmites australis; wetlands; farmland; paddy; photosynthesis; biomass

\section{Introduction}

Vegetation is a fundamental part of wetlands, so it is important to study the photosynthetic response mechanisms of vegetation for wetland protection [1,2]. Phragmites australis is one of the typical wetland plants and, therefore, studying the photosynthetic process of $P$. australis in differing environments is helpful in further understanding the response strategies of plants to different environmental conditions [3,4]. 
The physiological characteristics of photosynthetic carbon fixation in plants are mainly studied in terms of the effects of water (water level), salt [5], and heavy metal stress [6] on photosynthesis and fluorescence in plants. Combined with the plant community characteristics and growth characteristics, models are used to fit the photosynthetic carbon fixation process $[7,8]$. For example, the tolerance to flooding of four species, including $P$. australis, has been compared using isotopic techniques. The results showed that $P$. australis was the most tolerant plant because flooding resulted in an increase in the stomatal conductance of $P$. australis, and anaerobic enzymes in the rhizosphere improved its tolerance; in addition, the high photosynthetic rate $(\mathrm{Pa})$ contributed to biomass accumulation and $\mathrm{CO}_{2}$ fixation during this period [9]. P. australis is more tolerant to short-term flooding than to high salinity [10] because these variables affect chemical oxygen demand (COD) and other indicators in water. The photosynthetic rate decreases with increases in chemical oxygen demand, and higher COD can interfere with plant metabolism [11]. Some plants can improve their tolerance to a high-salinity and heavy metal environment by secreting protective enzymes such as superoxide dismutase (SOD), but this only applies under low-salinity conditions; under high salinity, the ability of plants to produce SOD will decrease or even disappear, thus inhibiting plant growth due to reduced protection against heavy metal toxicity [12]. Moreover, high salinity stress also has a great influence on the chlorophyll content of plant leaves, leading to a decrease in Pa. At the same time, the decrease in Pa under low-salinity stress is related to stomatal closure, but after exceeding the concentration threshold, stomatal closure is no longer the main reason for the decrease in Pa [13].

The effect of the water level on plant photosynthesis is mainly reflected in the distribution of biomass in roots, stems, and leaves as well as the photosynthetic process. Generally, in the early growing season, the biomass is mainly distributed to the leaves and stems to facilitate photosynthetic carbon sequestration. In the middle of the growing season, it is mainly distributed to the stems, while in the late growing season, it is distributed to the roots. Under adequate water conditions, plants will further reduce the allocation of biomass to the roots and increase the allocation of biomass to the stems and leaves. However, in the case of water shortage, the biomass allocation in leaves will be reduced while being increased in roots [14]. As for the photosynthetic process, at different growth or breeding stages, the response of plant photosynthetic carbon sequestration characteristics to hydrological conditions also differs; by adjusting the stomatal conductance of leaves and its photosynthetic rate [15], plants can adapt to changes in water depth and evolve into different ecological types. Therefore, it is necessary to study the effects of hydrological conditions on the photosynthesis of plants in combination with biomass.

The carbon sources and sink functions of saline-alkaline wetlands, as a special type of inland wetland, differ from those of freshwater wetlands. In China, the Western Songnen Plain is one of the main distribution areas for saline-alkaline wetlands. According to the results of China's second national survey of wetland resources, there are $430 \mathrm{~km}^{2}$ of wetlands in Western Jilin Province, with reed marshes being dominant. Niuxintaobao Wetland is one of the typical distribution areas for reed marshes in the Western Songnen Plain. It is also a typical saline-alkaline reed marsh, with abundant reed resources, with a vegetation coverage rate of around $85 \%$ [16]. There is a distinct water gradient from the center to the shore in the Niuxintaobao Wetland, and the change in water gradient results in different reed habitats. Therefore, it is important to understand the photosynthetic adaptation strategies of $P$. australis to environmental changes in saline-alkaline wetlands. As such, based on model fitting, the two main objectives of this study were to (1) characterize the photosynthetic characteristics of P. australis in different environments and (2) discuss how P. australis responds to environmental changes on the microscale (for both light-dependent and -independent reactions). We anticipate that the findings from this study will help in further understanding the relationship between plants and the environment. 


\section{Results}

\subsection{Characteristics of Light Response Curve}

\subsubsection{Characteristics of Light Response Curve in the Growing Season}

During the growing season, the saturated light intensity (Im) of HP (hygrophilous type of P. australis) was the lowest, and the Im of PP (P. australis in drainage area of paddy field) was the highest. The apparent quantum efficiency (AQE) of FP ( $P$. australis in abandoned farmland) had the highest value, indicating that $P$. australis in abandoned farmland had the highest photosynthetic efficiency under low light conditions. The value for maximum net photosynthetic rate (Pmax) of PP was the highest, and its biomass $(\mathrm{Bm})$ per unit area was also higher than that of other habitats (Table 1 and Figure 1). The rate of dark respiration ( $\mathrm{Rd})$ of PP was also the lowest among the five habitats. Thus, higher Pmax and lower Rd appear to be beneficial for the accumulation of biomass in the growth stage.

Table 1. Photosynthetic physiological characteristics of P. australis in the growing season (Im: saturated light intensity; AQE: apparent quantum efficiency; Rd: rate of dark respiration; Pmax: maximum net photosynthetic rate; Bm: biomass; HP: hygrophilous type of P. australis; XP: xerophytic type of P. australis; SP: psammophytic type of $P$. australis; FP: P. australis in abandoned farmland; PP: P. australis in drainage area of paddy field). Different letters after the values indicate statistically significant differences between five habitats in the same row. LSD: use "least significant difference" as a method when test the differences between variables.

\begin{tabular}{llllll}
\hline $\begin{array}{l}\text { Photosynthetic } \\
\text { Physiological } \\
\text { Characteristics }\end{array}$ & HP & XP & SP & FP & PP \\
\hline Im & $1046.9 \pm 12.3 \mathrm{a}$ & $1118.7 \pm 5.7 \mathrm{a}$ & $1261.3 \pm 11.2 \mathrm{~b}$ & $2165.3 \pm 21.7 \mathrm{c}$ & $2278.1 \pm 20.3 \mathrm{~d}$ \\
AQE & $0.029 \pm 0.004 \mathrm{a}$ & $0.021 \pm 0.003 \mathrm{a}$ & $0.039 \pm 0.002 \mathrm{~b}$ & $0.047 \pm 0.004 \mathrm{c}$ & $0.031 \pm 0.003 \mathrm{a}$ \\
Rd & $-0.65 \pm 0.02 \mathrm{a}$ & $-0.45 \pm 0.01 \mathrm{~b}$ & $-0.55 \pm 0.03 \mathrm{c}$ & $-0.45 \pm 0.07 \mathrm{~b}$ & $-0.29 \pm 0.02 \mathrm{~d}$ \\
Pmax & $11.70 \pm 0.13 \mathrm{a}$ & $11.30 \pm 0.25 \mathrm{~b}$ & $13.00 \pm 0.24 \mathrm{c}$ & $9.30 \pm 0.11 \mathrm{~d}$ & $19.60 \pm 0.17 \mathrm{e}$ \\
Bm & $137.0 \pm 2.7 \mathrm{a}$ & $133.3 \pm 3.5 \mathrm{~b}$ & $144.5 \pm 5.4 \mathrm{c}$ & $75.2 \pm 6.8 \mathrm{~d}$ & $218.3 \pm 5.9 \mathrm{e}$ \\
\hline
\end{tabular}

Note: Means $(n=10)$ followed by different letters are significantly different by LSD $(p<0.05)$.

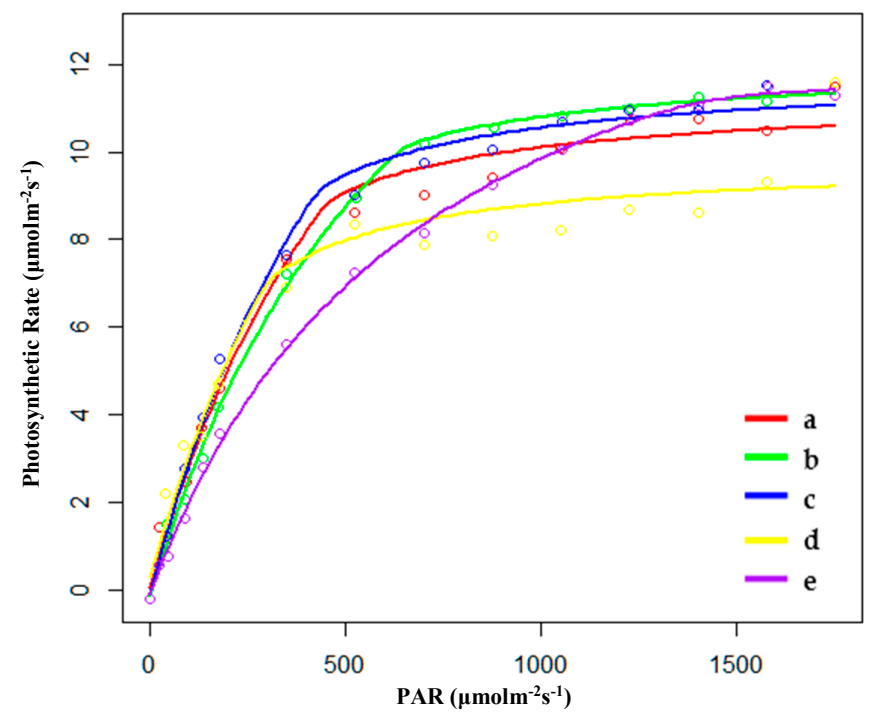

Figure 1. Fitting results of light response curves of (a) hygrophilous type of $P$. australis, (b) xerophytic type of $P$. australis, (c) psammophytic type of P. australis, (d) P. australis in abandoned farmland, and (e) P. australis in paddy field drainage during the growing season. PAR: photosynthetically active radiation. 


\subsubsection{Characteristics of Light Response Curve in the Breeding Season}

During the breeding season, the saturated light intensity (Im) of PP was the lowest, and the Im of FP was the highest. There were no significant differences in the rate of dark respiration (Rd) between HP (hygrophilous type of P. australis) and XP (xerophytic type of P. australis). SP (psammophytic type of $P$. australis) had the lowest biomass. The order of AQE was $\mathrm{FP}<\mathrm{HP}<\mathrm{XP}<\mathrm{PP}<\mathrm{SP}$, and the order of Pmax was FP $<\mathrm{PP}<\mathrm{HP}<\mathrm{XP}<\mathrm{SP}$. SP had the highest values for AQE and Pmax. Furthermore, SP also had the lowest Rd. However, PP still had the largest biomass (Table 2 and Figure 2). Therefore, there may be other factors that determined the accumulation of biomass in the stage of breeding. At the same time, after entering the breeding season, the change in Pmax varied depending on the habitat. The Pmax of SP and PP changed greatly. The Pmax of SP increased by around 50\% while the Pmax of PP decreased by $50.5 \%$. However, the Pmax of the others did not change significantly; the Pmax of HP and FP decreased while that of XP increased.

Table 2. Photosynthetic physiological characteristics of P. australis in the breeding season (Im: saturated light intensity; AQE: apparent quantum efficiency; Rd: rate of dark respiration; Pmax: maximum net photosynthetic rate; Bm: biomass; HP: hygrophilous type of P. australis; XP: xerophytic type of P. australis; SP: psammophytic type of P. australis; FP: P. australis in abandoned farmland; PP: P. australis in drainage area of paddy field). Different letters after the values indicate statistically significant differences between five habitats in the same row. LSD: use "least significant difference" as a method when test the differences between variables.

\begin{tabular}{llllll}
\hline $\begin{array}{l}\text { Photosynthetic } \\
\text { Physiological } \\
\text { Characteristics }\end{array}$ & HP & XP & SP & FP & PP \\
\hline Im & $2086.7 \pm 11.4 \mathrm{a}$ & $1810.2 \pm 4.9 \mathrm{~b}$ & $1838.3 \pm 11.9 \mathrm{c}$ & $2186.3 \pm 12.5 \mathrm{~d}$ & $924.1 \pm 9.2 \mathrm{e}$ \\
AQE & $0.011 \pm 0.003 \mathrm{a}$ & $0.017 \pm 0.004 \mathrm{~b}$ & $0.033 \pm 0.003 \mathrm{c}$ & $0.007 \pm 0.002 \mathrm{~d}$ & $0.025 \pm 0.005 \mathrm{e}$ \\
Rd & $-0.15 \pm 0.06 \mathrm{a}$ & $-0.14 \pm 0.03 \mathrm{a}$ & $-0.05 \pm 0.02 \mathrm{~b}$ & $-0.35 \pm 0.01 \mathrm{c}$ & $-0.20 \pm 0.04 \mathrm{~d}$ \\
Pmax & $11.50 \pm 0.26 \mathrm{a}$ & $14.30 \pm 0.19 \mathrm{~b}$ & $19.50 \pm 0.27 \mathrm{c}$ & $9.00 \pm 0.14 \mathrm{~d}$ & $9.50 \pm 0.24 \mathrm{~d}$ \\
Bm & $448.3 \pm 3.1 \mathrm{a}$ & $250.0 \pm 2.3 \mathrm{~b}$ & $166.7 \pm 7.4 \mathrm{c}$ & $365.0 \pm 8.6 \mathrm{~d}$ & $665.3 \pm 7.5 \mathrm{e}$ \\
\hline
\end{tabular}

Note: Means $(n=10)$ followed by different letters are significantly different by LSD $(p<0.05)$.

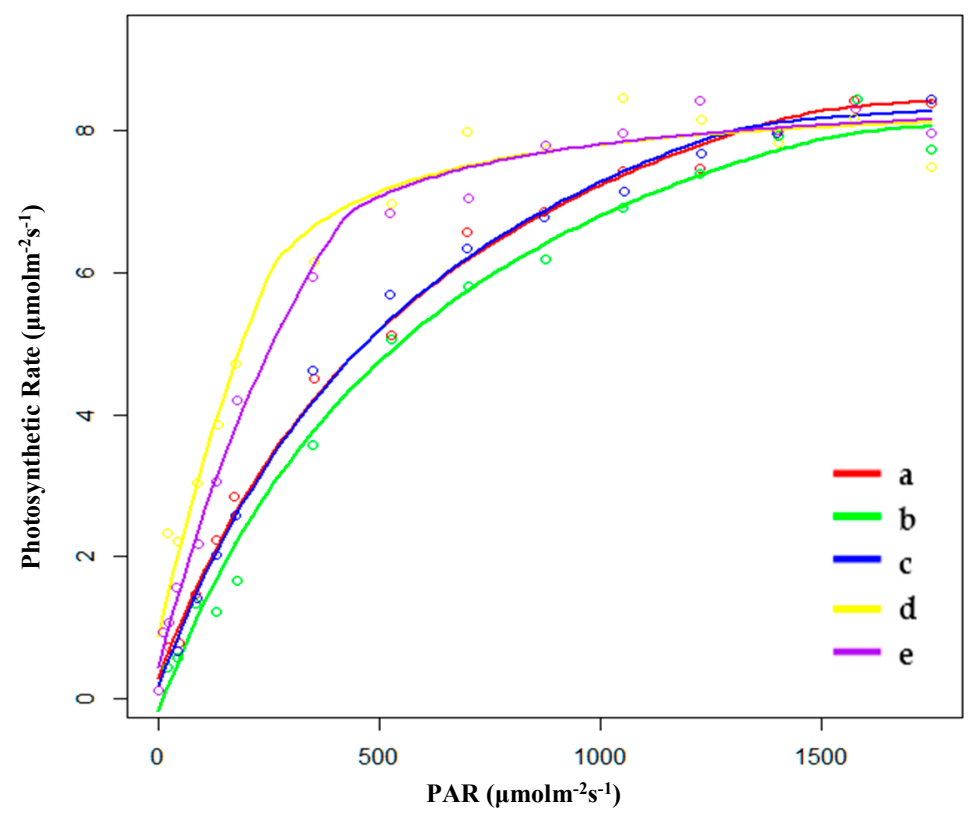

Figure 2. Fitting results of light response curves of (a) hygrophilous type of $P$. australis, (b) xerophytic type of P. australis, (c) psammophytic type of P. australis, (d) P. australis in abandoned farmland, and (e) P. australis in paddy field drainage during the breeding season. PAR: photosynthetically active radiation. 


\subsection{Characteristics of $\mathrm{CO}_{2}$ Response Curve}

\subsubsection{Characteristics of $\mathrm{CO}_{2}$ Response Curve in the Growing Season}

During the growing season, the order of $\mathrm{CO}_{2}$ saturation point $(\mathrm{Cm})$ was $\mathrm{PP}<\mathrm{SP}<\mathrm{XP}<\mathrm{HP}<\mathrm{FP}$; the order of $\mathrm{CO}_{2}$ compensation point (Cc) was $\mathrm{SP}<\mathrm{PP}<\mathrm{XP}<\mathrm{HP}<\mathrm{FP}$ (Table 3 and Figure 3). FP had the highest $\mathrm{Cm}$ and $\mathrm{Cc}$, indicating that $\mathrm{FP}$ could make use of a wide range of concentrations of $\mathrm{CO}_{2}$. However, the quantum efficiency of $\mathrm{CO}_{2}\left(\varphi \mathrm{CO}_{2}\right)$ of $\mathrm{FP}$ was the lowest, indicating that the utilization efficiency of low-concentration $\mathrm{CO}_{2}$ for $\mathrm{FP}$ was lower than compared to other conditions; this may be why FP needed to make use of a wide range of concentrations of $\mathrm{CO}_{2}$. PP had the highest value of $\varphi \mathrm{CO}_{2}$, and its rate of respiration (Rl) and photosynthetic capacity $(\mathrm{Pa})$ were also the largest among the five habitats. However, as mentioned before, PP still had the largest biomass; a higher respiratory rate would not be enough to affect the biomass accumulation.

Table 3. Characteristics of $\mathrm{CO}_{2}$ response curve of P. australis in the growing season $\left(\mathrm{Cm}: \mathrm{CO}_{2}\right.$ saturation point; $\mathrm{Cc}$ : $\mathrm{CO}_{2}$ compensation point; $\varphi \mathrm{CO}_{2}$ : the highest quantum efficiency of $\mathrm{CO}_{2}$; $\mathrm{Rl}$ : rate of respiration; Pa: photosynthetic capacity; HP: hygrophilous type of P. australis; XP: xerophytic type of P. australis; SP: psammophytic type of P. australis; FP: P. australis in abandoned farmland; PP: P. australis in drainage area of paddy field). Different letters after the values indicate statistically significant differences between five habitats in the same row. LSD: use "least significant difference" as a method when test the differences between variables.

\begin{tabular}{llllll}
\hline $\begin{array}{l}\text { Photosynthetic } \\
\text { Parameters }\end{array}$ & HP & XP & SP & FP & PP \\
\hline $\mathrm{Cm}$ & $2195.7 \pm 11.9 \mathrm{a}$ & $1708.2 \pm 4.0 \mathrm{~b}$ & $1678.9 \pm 11.2 \mathrm{c}$ & $3782.7 \pm 12.0 \mathrm{~d}$ & $1334.9 \pm 6.2 \mathrm{e}$ \\
$\mathrm{Cc}$ & $13.8 \pm 2.1 \mathrm{a}$ & $12.5 \pm 2.2 \mathrm{~b}$ & $6.3 \pm 0.4 \mathrm{c}$ & $48.6 \pm 3.6 \mathrm{~d}$ & $12.2 \pm 0.5 \mathrm{~b}$ \\
$\varphi \mathrm{CO}_{2}$ & $0.037 \pm 0.004 \mathrm{a}$ & $0.045 \pm 0.002 \mathrm{~b}$ & $0.067 \pm 0.001 \mathrm{c}$ & $0.025 \pm 0.001 \mathrm{~d}$ & $0.097 \pm 0.005 \mathrm{e}$ \\
$\mathrm{Rl}$ & $-0.50 \pm 0.02 \mathrm{a}$ & $-0.05 \pm 0.01 \mathrm{~b}$ & $-0.40 \pm 0.03 \mathrm{a}$ & $-1.20 \pm 0.02 \mathrm{c}$ & $-1.30 \pm 0.04 \mathrm{c}$ \\
$\mathrm{Pa}$ & $26.70 \pm 0.23 \mathrm{a}$ & $26.30 \pm 0.32 \mathrm{~b}$ & $26.60 \pm 0.17 \mathrm{a}$ & $28.10 \pm 0.34 \mathrm{c}$ & $30.70 \pm 0.37 \mathrm{~d}$ \\
\hline
\end{tabular}

Note: Means $(n=10)$ followed by different letters are significantly different by LSD $(p<0.05)$.

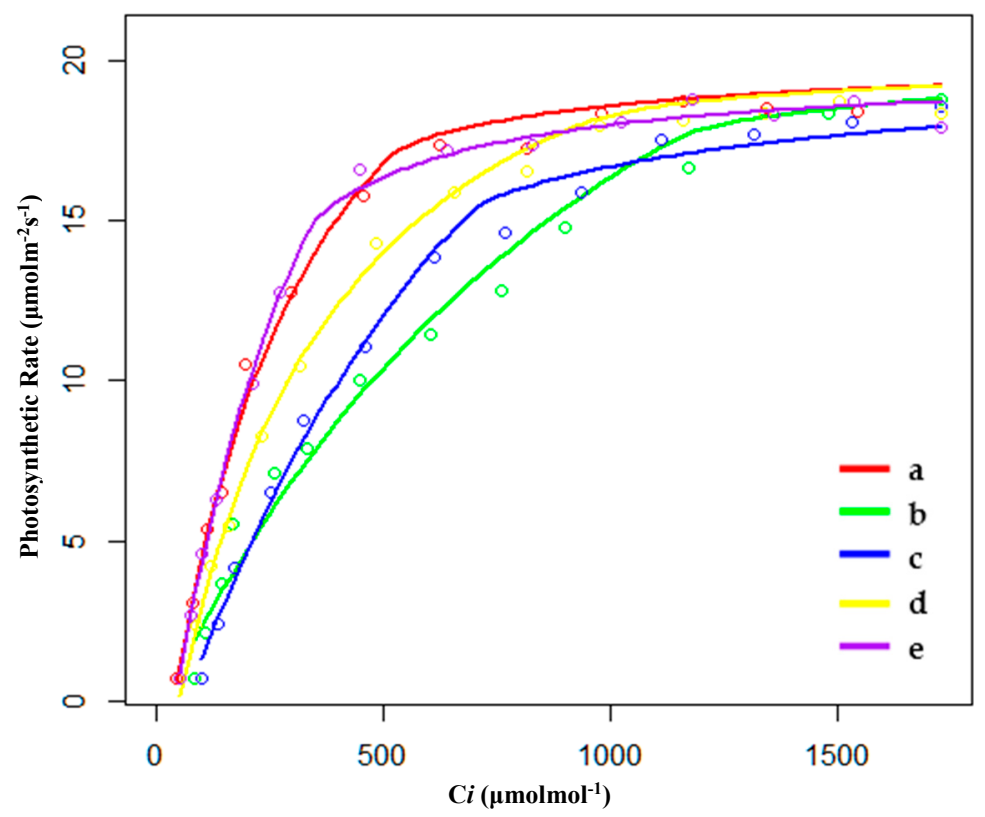

Figure 3. Fitting results of $\mathrm{CO}_{2}$ response curves of (a) hygrophilous type of $P$. australis, (b) xerophytic type of P. australis, (c) psammophytic type of P. australis, (d) P. australis in abandoned farmland, and (e) $P$. australis in paddy field drainage during the growing season. $\mathrm{C} i$ intercellular $\mathrm{CO}_{2}$ concentration. 


\subsubsection{Characteristics of $\mathrm{CO}_{2}$ Response Curve in the Breeding Season}

During the breeding season, the order of $\mathrm{CO}_{2}$ saturation point $(\mathrm{Cm})$ was $\mathrm{SP}<\mathrm{PP}<\mathrm{XP}<\mathrm{HP}<\mathrm{FP}$, and the order of $\mathrm{CO}_{2}$ compensation point (Cc) was $\mathrm{SP}<\mathrm{HP}<\mathrm{XP}<\mathrm{PP}<\mathrm{FP}$ (Table 4 and Figure 4); hence, the values of $\mathrm{Cm}$ and $\mathrm{Cc}$ were still the highest for FP. Moreover, the quantum efficiency of $\mathrm{CO}_{2}\left(\varphi \mathrm{CO}_{2}\right)$ of FP was also the lowest, indicating that FP still needed to make use of a wide range of $\mathrm{CO}_{2}$ concentrations. The photosynthetic capacity $(\mathrm{Pa})$ was similar to that of the growing season, i.e., under conditions of sufficient light and $\mathrm{CO}_{2}$, P. australis showed strong photosynthetic capacity in five habitats, especially in the drainage area of paddy field (PP). However, compared with the growth period, the photosynthetic capacity ( $\mathrm{Pa}$ ) of $\mathrm{PP}, \mathrm{HP}$, and FP decreased, while that of XP and SP increased.

Table 4. Characteristics of $\mathrm{CO}_{2}$ response curve of $P$. australis in the breeding season $\left(\mathrm{Cm}: \mathrm{CO}_{2}\right.$ saturation point; $\mathrm{Cc}$ : $\mathrm{CO}_{2}$ compensation point; $\varphi \mathrm{CO}_{2}$ : the highest quantum efficiency of $\mathrm{CO}_{2}$; $\mathrm{Rl}$ : rate of respiration; Pa: photosynthetic capacity; HP: hygrophilous type of P. australis; XP: xerophytic type of P. australis; SP: psammophytic type of P. australis; FP: P. australis in abandoned farmland; PP: P. australis in drainage area of paddy field). Different letters after the values indicate statistically significant differences between five habitats in the same row. LSD: use "least significant difference" as a method when test the differences between variables.

\begin{tabular}{llllll}
\hline $\begin{array}{l}\text { Photosynthetic } \\
\text { Parameters }\end{array}$ & HP & XP & SP & FP & PP \\
\hline $\mathrm{Cm}$ & $3417.9 \pm 11.2 \mathrm{a}$ & $2791.7 \pm 4.6 \mathrm{~b}$ & $1486.4 \pm 11.2 \mathrm{c}$ & $5465.8 \pm 17.5 \mathrm{~d}$ & $2363.1 \pm 9.0 \mathrm{e}$ \\
$\mathrm{Cc}$ & $12.9 \pm 0.7 \mathrm{a}$ & $15.2 \pm 1.3 \mathrm{~b}$ & $5.9 \pm 0.3 \mathrm{c}$ & $59.7 \pm 8.8 \mathrm{~d}$ & $35.4 \pm 2.7 \mathrm{e}$ \\
$\varphi \mathrm{CO}_{2}$ & $0.021 \pm 0.003 \mathrm{a}$ & $0.039 \pm 0.002 \mathrm{~b}$ & $0.017 \pm 0.003 \mathrm{c}$ & $0.011 \pm 0.002 \mathrm{~d}$ & $0.049 \pm 0.003 \mathrm{e}$ \\
$\mathrm{Rl}$ & $-0.05 \pm 0.006 \mathrm{a}$ & $-1.1 \pm 0.05 \mathrm{~b}$ & $-0.85 \pm 0.03 \mathrm{c}$ & $-0.65 \pm 0.03 \mathrm{~d}$ & $-1.75 \pm 0.1 \mathrm{e}$ \\
$\mathrm{Pa}$ & $25.10 \pm 0.70 \mathrm{a}$ & $28.60 \pm 0.23 \mathrm{~b}$ & $28.70 \pm 0.37 \mathrm{~b}$ & $26.20 \pm 0.45 \mathrm{c}$ & $29.40 \pm 0.68 \mathrm{~d}$ \\
\hline
\end{tabular}

Note: Means $(n=10)$ followed by different letters are significantly different by LSD $(p<0.05)$.

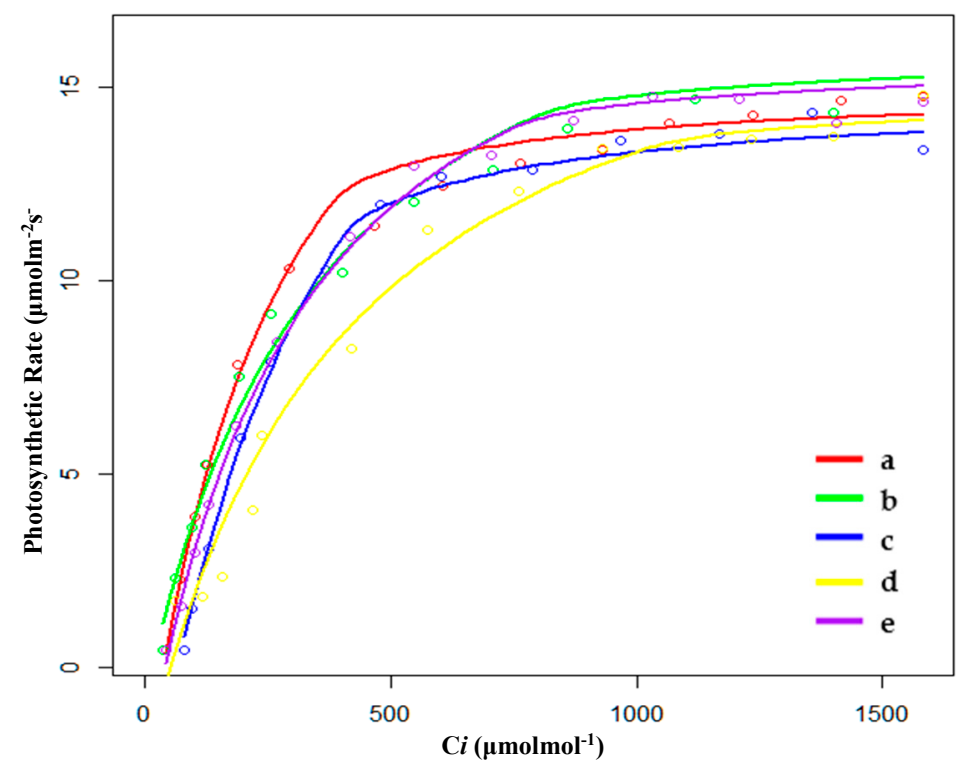

Figure 4. Fitting results of $\mathrm{CO}_{2}$ response curves of (a) hygrophilous type of $P$. australis, (b) xerophytic type of $P$. australis, (c) psammophytic type of P. australis, (d) P. australis in abandoned farmland, and (e) $P$. australis in paddy field drainage during the breeding season. $\mathrm{C} i$ : intercellular $\mathrm{CO}_{2}$ concentration. 


\section{Discussion}

\subsection{Photosynthetic Characteristics of P. australis in the Growing Season}

The fitting results for the light response curve demonstrated that apparent quantum efficiency (AQE) was one of the most important indicators for characterizing the ability of plants to assimilate $\mathrm{CO}_{2}$ under low light conditions. The slope of the light response curve at the weak light stage (i.e., the smaller PAR value interval) was calculated as the apparent quantum efficiency, which means the average amount of $\mathrm{CO}_{2}$ assimilated by one photon $[17,18]$. During the growing season, the AQE of FP was the highest $(0.047 \pm 0.004)$ in five habitats, indicating that FP had a strong ability to utilize weak light. Field investigations also revealed that in abandoned farmland, P. australis mainly grew in a shady environment (shading by trees is one of the reasons leading to the abandonment of farmland). Furthermore, the high AQE also indicated that P. australis adapted to long-term shading, indicating that it had higher photosynthetic efficiency in weak light. The rate of respiration represents the rate at which plants consume organic matter. It is generally believed that a higher respiration rate is not conducive to the accumulation of organic matter. Maximum photosynthetic rate (Pmax) represents the ability to assimilate $\mathrm{CO}_{2}$ under sufficient light; the higher the value of Pmax, the higher the rate of carbon sequestration, and the more favorable it is for the accumulation of organic matter $[19,20]$. PP had the highest Pmax and the lowest respiration rate. Therefore, the general rule of biomass accumulation of $P$. australis in five habitats was as follows: the higher the value of Pmax, the larger the biomass. Studies have found that rich soil nutrient content is conducive to the accumulation of photosynthetic carbon sequestration of plants [21,22]. The reason for PP's greater Pmax is presumed to be related to the use of fertilizers in paddy fields, which indirectly results in higher $\mathrm{N}, \mathrm{P}$, and other nutrient elements in soil than in other habitats, which is more conducive to the fixation of $\mathrm{CO}_{2}$ and accumulation of organic matter [23]. However, PP had the lowest Pmax. Some studies have shown that $P$. australis can regulate its genes, to some extent, to adapt to high-salinity environments. These genetic regulations include higher relative expression levels of genes associated with photosynthesis and lignan biosynthesis, indicative of a greater ability to maintain growth under saline conditions [24]. At the same time, the distribution of photosynthetically fixed $C$ in roots and soils also changes, for example, with lower contents of photosynthetically fixed $C$ in roots and higher contents in soil [25].

Photosynthetic capacity $(\mathrm{Pa})$ is one of the most important indicators for analyzing the characteristics of the $\mathrm{CO}_{2}$ response curve. It is used to characterize the maximum potential of fixing $\mathrm{CO}_{2}$ under conditions of sufficient light and $\mathrm{CO}_{2}$. Photorespiration refers to the consumption of superfluous substances by respiration when high amounts of $[\mathrm{H}]$ and ATP accumulate in the photoreaction but the photosynthetic dark reaction is inhibited so as to prevent their accumulation, affecting plant metabolism [26-29]. Therefore, the rate of photorespiration (Rl) in plants can reflect their photoreaction rate to a certain extent, and this then affects the final net photosynthetic rate. During the growing season, the general rule for the photosynthetic capacity of $P$. australis in the five studied habitats was that the higher the $\mathrm{Rl}$ value, the higher the Pa value. The Rl of PP was the highest, and the Pa of PP was also the highest among the five habitats. Moreover, the $\mathrm{CO}_{2}$ quantum efficiency $\left(\varphi \mathrm{CO}_{2}\right)$ of PP was also the highest, indicating that it had the highest photosynthetic efficiency for low concentrations of $\mathrm{CO}_{2}$.

By further fitting the $\mathrm{CO}_{2}$ response curve, the limits for the photosynthetic rate in the dark reaction process were obtained for different intercellular $\mathrm{CO}_{2}$ concentrations (Ci). Vc represents the limitation of Rubisco carboxylase and J represents the limitation of RuBP (ribulose bisphosphate) regeneration. Therefore, the intersection point (Ci_transition) of the Vc-limit curve (blue) and J-limit curve (red) was the demarcation between the limitation of Rubisco carboxylase and the limitation of $\mathrm{RuBP}$ regeneration. When $\mathrm{C}<\mathrm{Ci}$ _transition, the photosynthetic rate is mainly limited by $\mathrm{V}_{\mathrm{c}}$, and when $\mathrm{C}>\mathrm{C}$ i_transition, the photosynthetic rate is mainly limited by J [30,31]. According to the fitting results, during the growing season, the Vcmax and Jmax of PP were the highest among the five habitats, and the photosynthetic capacity (Pa) of PP was also the highest (Table 5 and Figure 5). Moreover, the value of Ci_transition of PP was 308 ppm, which was lower than the general environmental $\mathrm{CO}_{2}$ 
concentration (around $400 \mathrm{ppm}$ ). Therefore, the photosynthetic rate of PP was mainly determined by Vc and J, while the photosynthetic rates of others were mainly determined by Vc.

Table 5. Characteristics of photosynthetic dark reaction of P. australis in the growing season (Vcmax: maximum carboxylation rate; Jmax: maximum electron transfer rate; $\mathrm{Ci}$ _transition: intersection point of the Vc-limit curve (blue) and J-limit curve (red); HP: hygrophilous type of P. australis; XP: xerophytic type of P. australis; SP: psammophytic type of P. australis; FP: P. australis in abandoned farmland; PP: $P$. australis in drainage area of paddy field). Different letters after the values indicate statistically significant differences between five habitats in the same row. LSD: use "least significant difference" as a method when test the differences between variables.

\begin{tabular}{llllll}
\hline $\begin{array}{l}\text { Photosynthetic } \\
\text { Parameters }\end{array}$ & HP & XP & SP & FP & PP \\
\hline Vcmax & $94.53 \pm 2.61 \mathrm{a}$ & $41.47 \pm 2.04 \mathrm{~b}$ & $53.76 \pm 3.23 \mathrm{c}$ & $70.59 \pm 1.62 \mathrm{~d}$ & $138.99 \pm 3.93 \mathrm{e}$ \\
Jmax & $148.28 \pm 2.51 \mathrm{a}$ & $107.29 \pm 1.32 \mathrm{~b}$ & $111.57 \pm 3.91 \mathrm{~b}$ & $115.13 \pm 2.10 \mathrm{~b}$ & $195.75 \pm 2.85 \mathrm{c}$ \\
Ci_transition & 530 & 787 & 519 & 828 & 308 \\
\hline
\end{tabular}

Note: Means $(n=10)$ followed by different letters are significantly different by LSD $(p<0.05)$.

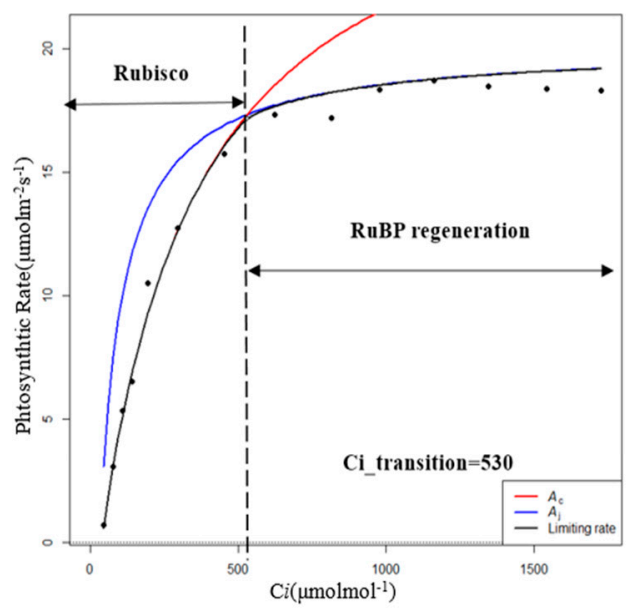

b

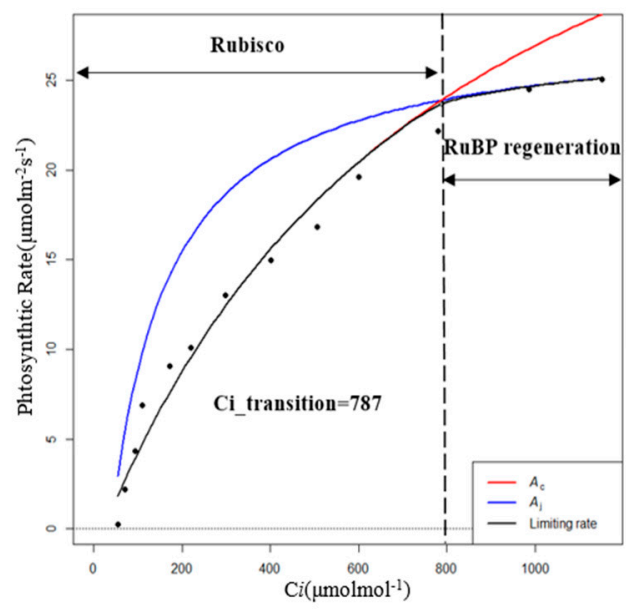

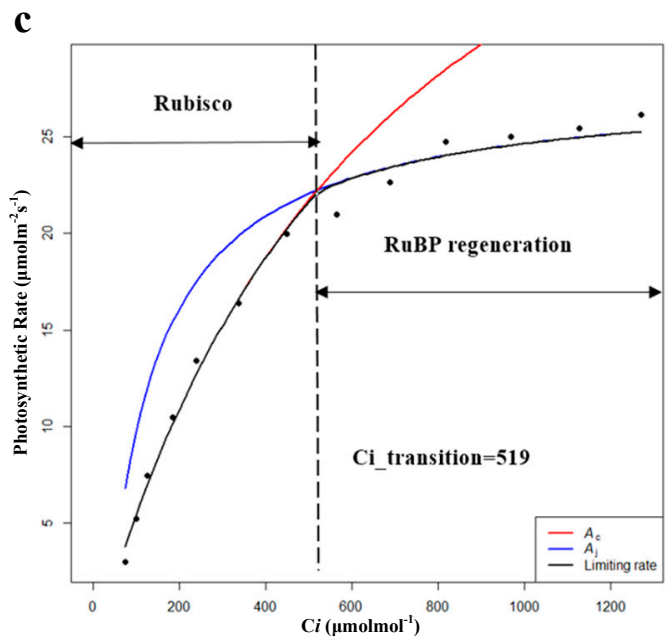

Figure 5. Cont. 
d

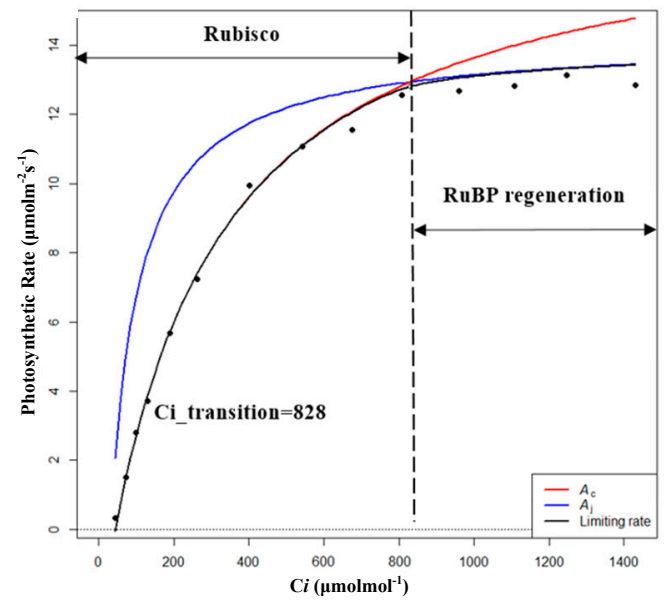

e

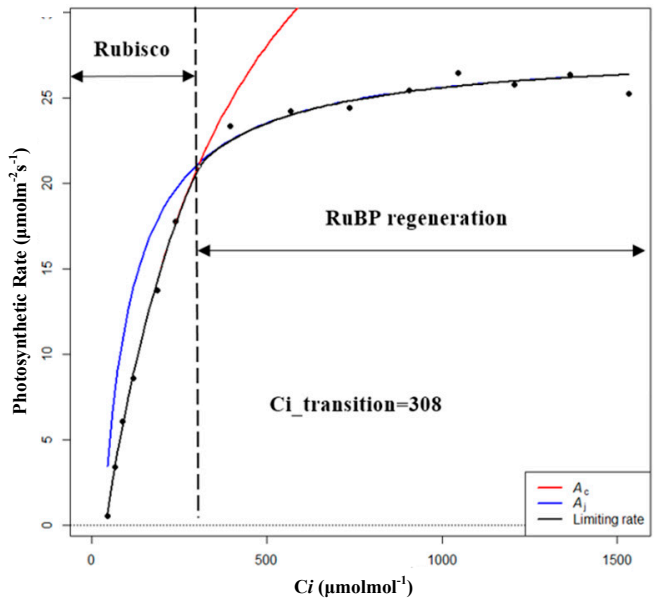

Figure 5. Modeling results of photosynthetic rate limitations of (a) hygrophilous type of P. australis, (b) xerophytic type of $P$. australis, (c) psammophytic type of $P$. australis, (d) $P$. australis in abandoned farmland, and (e) $P$. australis in paddy field drainage during the growing season. $A_{c}$ is the gross photosynthetic rate when Rubisco activity is limiting; $A_{j}$ is the gross photosynthetic rate when RuBP regeneration is limiting (RuBP: ribulose bisphosphate; $\mathrm{C} i$ intercellular $\mathrm{CO}_{2}$ concentration).

\subsection{Photosynthetic Characteristics of P. australis in the Breeding Season}

By comparing the characteristics of light response curves, reeds in all habitats showed an increase in the value of the light saturation point (Im) and a decrease in the value of AQE after entering the breeding season, which meant a gradual adaptation to and utilization of the high-light environment. It was believed that the general downward trend observed for the value of AQE during the process of plant growth may be related to the increase in average solar radiation intensity [32]. Meanwhile, the rates of dark respiration of $P$. australis in all habitats were lower than those of the growing season, and the biomass showed accumulation with a decrease in the rates of dark respiration. Moreover, the rate of biomass accumulation of FP was the highest among the five habitats (386.7\%). However, the Pmax of HP, FP, and PP showed a downward trend. The decrease in photosynthetic rate was related to the decrease in stomatal conductance, and the decrease in stomatal conductance was related to the increase in salinity [33]. Some studies have shown that reeds could adapt to a saline and alkaline environment by rapid ecological evolution and phenotypic differentiation. At the same time, reeds could also adapt to a harsh environment by reducing the photosynthetic rate or chlorophyll concentration and increasing the $\mathrm{K}^{+}$concentration in leaves [34-36].

By comparing the characteristics of $\mathrm{CO}_{2}$ response curves, reeds in all habitats showed a decrease in the value of $\mathrm{CO}_{2}$ quantum efficiency $\left(\varphi \mathrm{CO}_{2}\right)$ after entering the breeding season, which represents an adaptation to high concentrations of $\mathrm{CO}_{2}$. Except for $\mathrm{HP}$, reeds in all habitats showed an increase in the value of $\mathrm{CO}_{2}$ compensation points $(\mathrm{Cc})$, which meant decreased photosynthetic sensitivity to low concentrations of $\mathrm{CO}_{2}$. In addition, $\mathrm{PP}$ had the highest $\varphi \mathrm{CO}_{2}, \mathrm{Rl}$, and $\mathrm{Pa}$ in both the growing and breeding seasons. Moreover, Vcmax and Jmax as well as Pmax and Pn of XP and SP showed an upward trend while showing a downward trend for HP, FP, and PP (Table 6 and Figure 6). The results showed that the fitting results of the light response curves and the $\mathrm{CO}_{2}$ response curves were consistent. It was also found that XP and SP entered the withering season later than HP, FP, and PP during the field investigation, which may be related to the later decline in ability to undergo dark reaction (Vcmax, Jmax) of XP and SP. Therefore, Vcmax and Jmax, as important indicators reflecting the characteristics of photosynthetic dark reaction, could explain the changes in photosynthetic rate to some extent [37]. However, Vcmax and Jmax represent only the dark reaction part of photosynthesis, and if combined with the chlorophyll fluorescence parameters, i.e., the characteristics of the light reaction part of 
photosynthesis, the variations in the photosynthetic rate will be explained more comprehensively. Hence, it is necessary to conduct further studies on the specific photosynthetic process of P. australis.

Table 6. Characteristics of photosynthetic dark reaction of P. australis in the breeding season (Vcmax: maximum carboxylation rate; Jmax: maximum electron transfer rate; $\mathrm{Ci}$ _transition: intersection point of the Vc-limit curve (blue) and J-limit curve (red); HP: hygrophilous type of P. australis; XP: xerophytic type of P. australis; SP: psammophytic type of P. australis; FP: P. australis in abandoned farmland; PP: $P$. australis in drainage area of paddy field). Different letters after the values indicate statistically significant differences between five habitats in the same row. LSD: use "least significant difference" as a method when test the differences between variables.

\begin{tabular}{llllll}
\hline $\begin{array}{l}\text { Photosynthetic } \\
\text { Parameters }\end{array}$ & HP & XP & SP & FP & PP \\
\hline Vcmax & $86.91 \pm 6.54 \mathrm{a}$ & $61.85 \pm 2.26 \mathrm{~b}$ & $94.26 \pm 3.19 \mathrm{c}$ & $30.21 \pm 0.89 \mathrm{~d}$ & $82.90 \pm 1.69 \mathrm{a}$ \\
Jmax & $120.02 \pm 4.77 \mathrm{a}$ & $116.62 \pm 3.53 \mathrm{a}$ & $154.89 \pm 3.08 \mathrm{~b}$ & $59.58 \pm 1.43 \mathrm{c}$ & $146.62 \pm 2.19 \mathrm{~b}$ \\
Ci_transition & 405 & 815 & 428 & 999 & 808 \\
\hline
\end{tabular}

Note: Means $(n=10)$ followed by different letters are significantly different by LSD $(p<0.05)$.

a

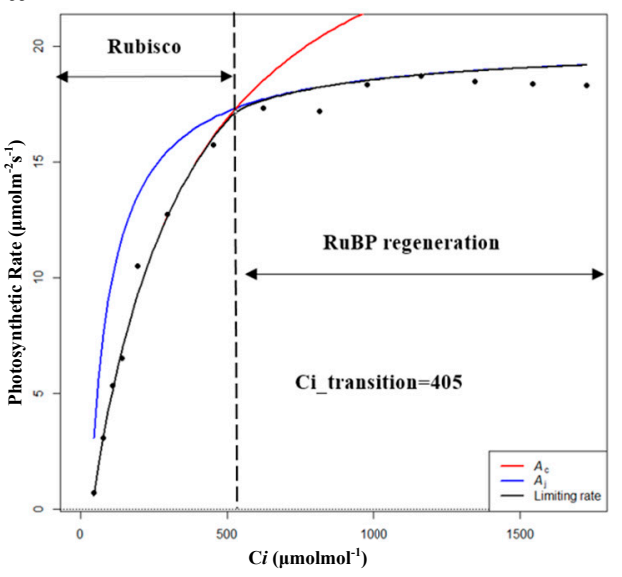

b

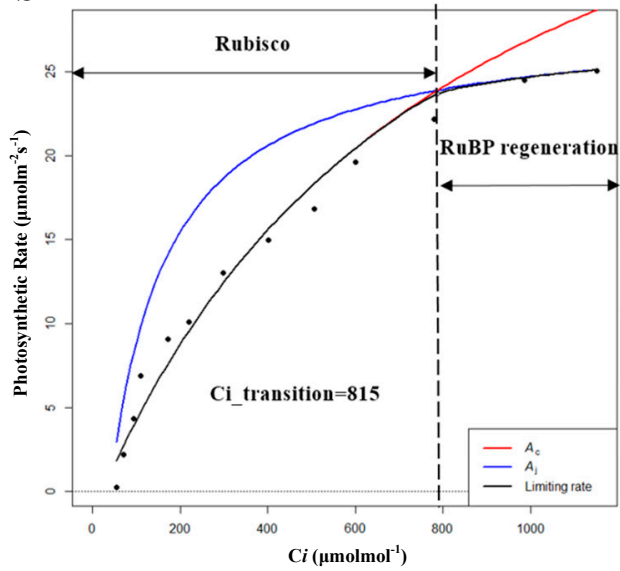

c

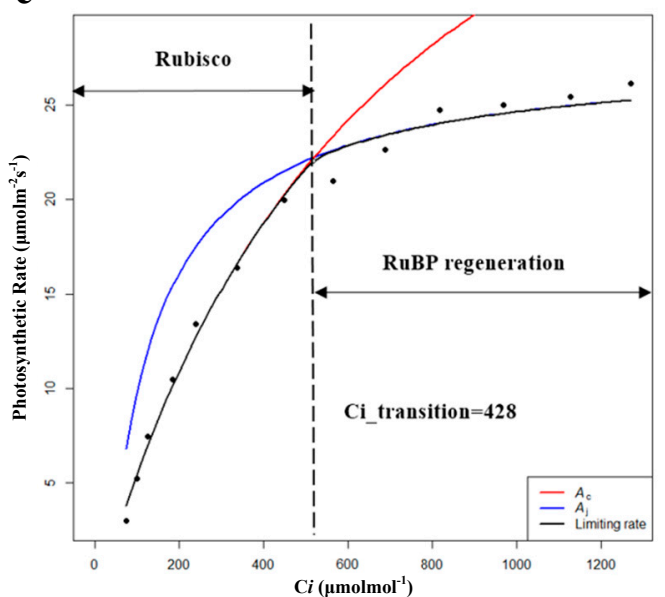

Figure 6. Cont. 

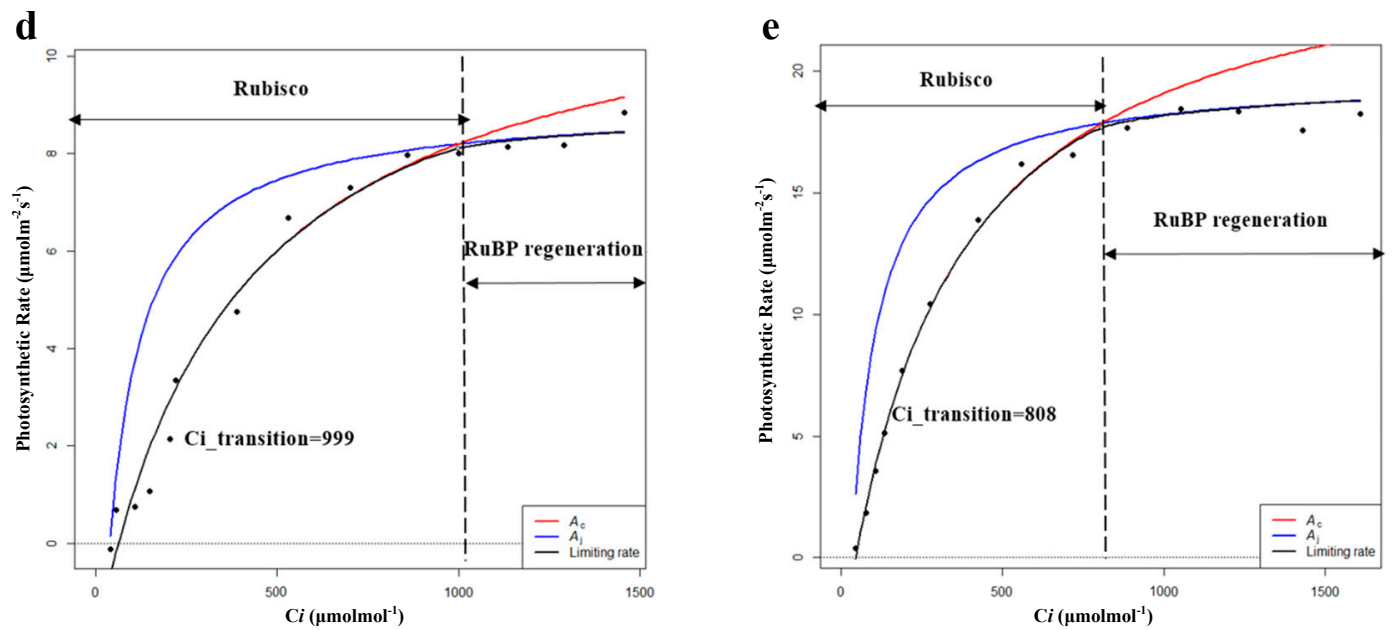

Figure 6. Modeling results of photosynthetic rate limitations of (a) hygrophilous type of P. australis, (b) xerophytic type of $P$. australis, (c) psammophytic type of $P$. australis, (d) $P$. australis in abandoned farmland, and (e) $P$. australis in paddy field drainage during the breeding season. $A_{c}$ is the gross photosynthetic rate when Rubisco activity is limiting; $A_{j}$ is the gross photosynthetic rate when RuBP regeneration is limiting (RuBP: ribulose bisphosphate; $\mathrm{C}$ : intercellular $\mathrm{CO}_{2}$ concentration).

\section{Materials and Methods}

\subsection{Study Area}

Niuxintaobao Wetland $\left(45^{\circ} 13^{\prime}-45^{\circ} 16^{\prime} \mathrm{N}, 123^{\circ} 13^{\prime}-123^{\circ} 21^{\prime} \mathrm{E}\right)$ is located in the west of Songnen Plain in Northeastern China (Figure 7). Administratively, it is within the provinces of Jilin and Heilongjiang of China. It is formed by water accumulation in the interfluvial lowlands caused by the hydraulic movement of Huolin and Taoer Rivers. It is moderately saline-alkaline, with an area of around $33 \mathrm{~km}^{2}$. The main source of water supply is Taoer River [38]. P. australis saline-alkaline marshes are distributed in the study region, and it is characterized by a typical semiarid and moderate monsoon climate with distinctive seasons; the total annual sunlight is $5259 \mathrm{MJ} / \mathrm{m}^{2}$, the frost-free period is $137 \mathrm{~d}$ of the year [39], and it is one of the typical distribution areas of reeds in inland China.

A field survey was carried out during May (growing season) and August (breeding season). Reed habitats were classified according to the measured soil moisture as follows: hygrophilous (HP), xerophytic (XP), psammophytic (SP), abandoned farmland (FP), or paddy field drainage (PP) [40]. Ten stands $(5 \mathrm{~m} \times 5 \mathrm{~m})$ in each habitat were selected and used as replicates for all habitats (Table 7 and Figure 7).

Table 7. Characteristics of five P. australis habitats.

\begin{tabular}{ccccc}
\hline Habitats & Density of Reed & Water Level (cm) & Soil Moisture $\mathbf{( \% )}$ & Area $\mathbf{( k m}^{\mathbf{2}} \mathbf{)}$ \\
\hline HP & 131 & $20-40$ & 43.12 & 2.48 \\
XP & 179 & 0 & 36.25 & 6.35 \\
SP & 25 & 0 & 18.29 & 2.93 \\
FP & 54 & 0 & 29.33 & 3.23 \\
PP & 126 & $30-60$ & 54.72 & 2.87 \\
\hline
\end{tabular}




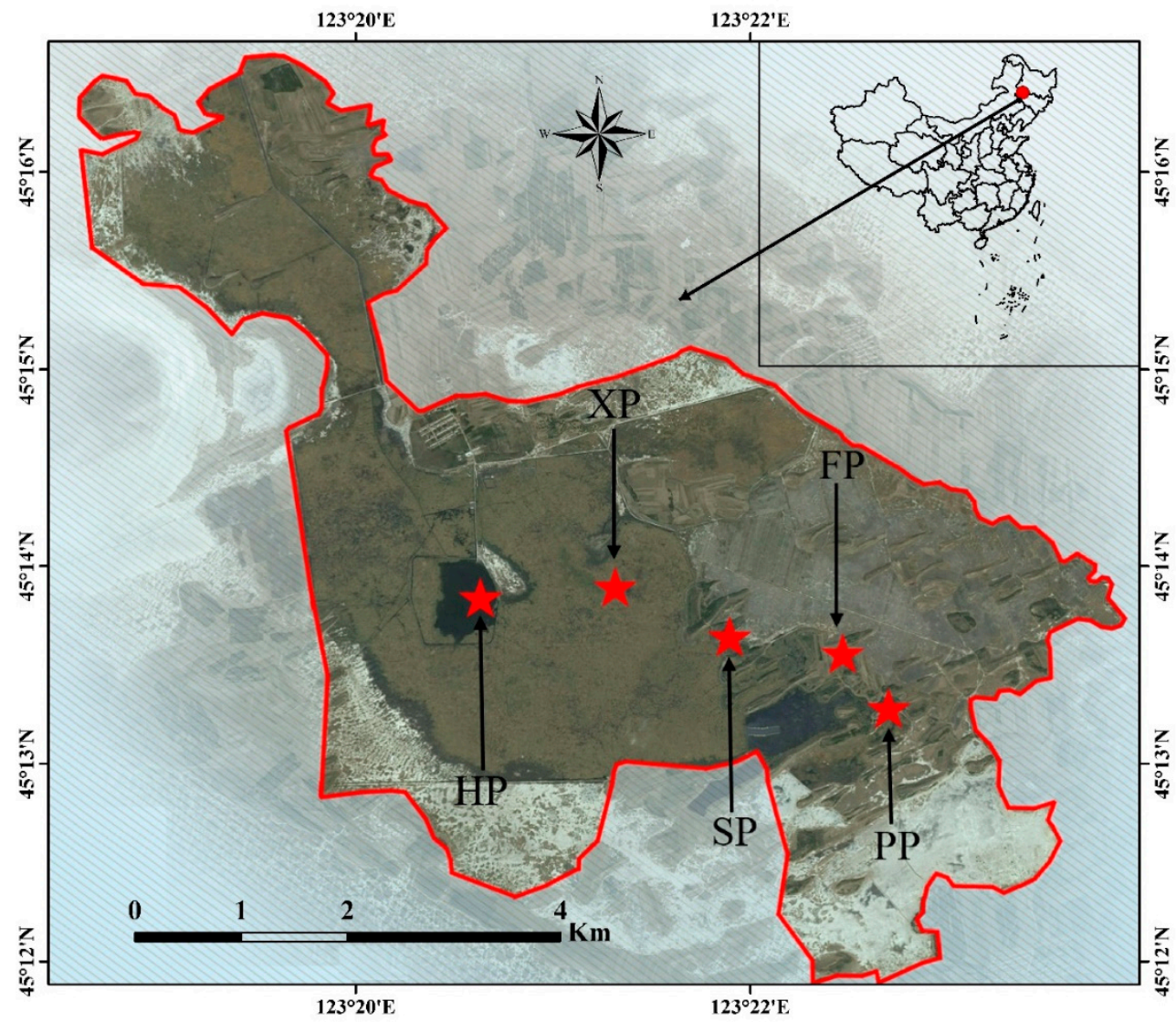

Figure 7. Location of the study area.

\subsection{Experimental Design}

\subsubsection{Biomass Collection}

There are non-destructive sampling methods using remote sensing spectroscopy for measuring plant biomass, and these methods are mainly used in the macro or large-scale research [41-46]. In order to directly reflect the characteristics of biomass, combined with the sampling methods commonly used by previous researchers [47-52], we chose the harvesting method to measure the biomass. That is, the aboveground parts of $P$. australis in five habitats were mowed in a $0.5 \mathrm{~m} \times 0.5 \mathrm{~m}$ square and then dried in an oven at $75{ }^{\circ} \mathrm{C}$ for $48 \mathrm{~h}$. The final weight was recorded when the weight showed no further reductions.

\subsubsection{Measurement of Light Response Curve}

The third top leaves of 10 shoots from each stand were used as replicates. The relative humidity was $45-50 \%$ and the temperature was around $25^{\circ} \mathrm{C}$. The light response curve was measured by LI-6400XT (LICOR, Lincoln, NE, USA) at 9:00-11:00 on a bright, clear day in May and August. Full light induction was carried out after installing the red and blue light source leaf chamber (6400-02B). After successful induction, the stable photo values under 15 light intensity (PAR, $\mu \mathrm{mol} / \mathrm{m}^{2} / \mathrm{s}$ ) gradients (2000, 1800, 1600, 1400, 1200, 1000, 800, 600, 400, 200, 150, 100, 50, 25, and 0) were selected and recorded in the file. Photo values were recorded in order of light intensity, from high to low. The standard of photo value recording is that the intake concentration of the instrument is stable without leakage; the stomatal conductance (Cond), intercellular $\mathrm{CO}_{2}$ concentration (Ci), and transpiration rate ( $\mathrm{Tr}$ ) of line $\mathrm{C}$ are all positive, the value of Cond is between 0 and 1 ; and the change rate of photo value $(\triangle \mathrm{P})$ is less than $2 \%$. 


\subsubsection{Measurement of $\mathrm{CO}_{2}$ Response Curve}

The leaves were the same as those used in measuring the light response curve. After full light induction, the $\mathrm{CO}_{2}$ mixer was used to control the $\mathrm{CO}_{2}$ concentration gradient of 2000, 1800, 1600, 1400, $1200,1000,800,600,400,200,150,100,50,25$, and 0 . The saturated light intensity $\left(2000 \mu \mathrm{mol} / \mathrm{m}^{2} / \mathrm{s}\right)$ was chosen as the light intensity. However, the photo values were recorded in the following order: 400, 200, $150,100,50,25,0,400,600,800,100,1200,1400,1600,1800$, and 2000. The standard of recording the photo value is the same as that of the measurement of the light response curve.

\subsection{Data Calculation and Analysis}

\subsubsection{Fitting Light Response Curve}

The fitting of light response curve is based on the nonrectangular hyperbolic model (Equation (1)) [53,54]:

$$
P n(I)=\frac{a I+P \max -\sqrt{(a I+P \max )^{2}-4 \theta a I P \max }}{2 \theta}-R d
$$

where $P n$ is the photosynthetic rate, $I$ is the light intensity, $a$ is the apparent quantum efficiency (AQE), $P$ max is the maximum photosynthetic rate, $R d$ is the respiratory rate, and $\theta$ is the correction coefficient. According to the formula, $I_{c}$ is set as the light compensation point, i.e., the value of $I$ when $P n(I)=0$, Im is the light saturation point, i.e., the value of $I$ when $P n^{\prime}(I)=0$, and $P n^{\prime}(I)$ is the first derivative of the function $P n(I)$.

\subsubsection{Fitting the $\mathrm{CO}_{2}$ Response Curve}

A nonrectangular hyperbolic model was also used to fit the $\mathrm{CO}_{2}$ response curve (Equation (2)) [55], but there are corresponding deformations when calculating Vcmax (represented by Ac in Equation (3)) and Jmax (represented by $A j$ in Equation (3)) [56]:

$$
P n(C)=\frac{a C+P a-\sqrt{(a C+P a)^{2}-4 \theta a C P a}}{2 \theta}-R l
$$

where $P n$ is the photosynthetic rate, $C$ is the $\mathrm{CO}_{2}$ concentration, $a$ is the $\mathrm{CO}_{2}$ quantum efficiency $\left(\varphi \mathrm{CO}_{2}\right), P a$ is the photosynthetic capacity, $R l$ is the respiratory rate, and $\theta$ is the correction coefficient. According to the formula, $C c$ is set as the $\mathrm{CO}_{2}$ compensation point, i.e., the value of $C$ when $\operatorname{Pn}(C)=0$, $\mathrm{Cm}$ is the $\mathrm{CO}_{2}$ saturation point, i.e., the value of $C$ when $P n^{\prime}(C)=0$, and $P n^{\prime}(C)$ is the first derivative of the function $\operatorname{Pn}(\mathrm{C})$.

$$
A m=\frac{A c+A j-\sqrt{(A c+A j)^{2}-4 \theta A c A j}}{2 \theta}-R l
$$

where $A m$ is the hyperbolic minimum of $A c$ and $A j, A c$ is the gross photosynthetic rate when Rubisco activity is limiting, $A j$ is the gross photosynthetic rate when RuBP regeneration is limiting, $R l$ is the respiratory rate, and $\theta$ is the correction coefficient.

\subsubsection{Statistical Analysis}

The least squares method was used to estimate the fit of the experimental data. The test of fitting results could be divided into a goodness of fit test and a significance test for the regression equation. The decision coefficient $R^{2}$ was used to verify the goodness of fit, and the $\mathrm{F}$ test was used to verify the significance of the regression equation. One-way ANOVA was used to test the differences in photosynthetic characteristics of $P$. australis in different habitats. The confidence intervals of all the analyses were $95 \%$. Statistical software SPSS22.0 for Windows (IBM Corp., Armonk, NY, USA) was 
used for the above statistical analyses, and the experimental data and regression model were also plotted and analyzed by R language software package "plantecophys", written by Remko Duursma [57] (v.3.4.2; R Foundation for Statistical Computing, Vienna, Australia).

\section{Conclusions}

This study was the first attempt to compare the response of P. australis to environmental changes from the perspective of the photosynthetic process. The findings indicate that with the transition from the growing season to the breeding season, P. australis showed decreased photosynthetic sensitivity, the rate of dark respiration also showed a downward trend, and plants were more conducive to the accumulation of biomass. P. australis in the drainage area of a paddy field benefited from abundant nutrition; its biomass and photosynthetic capacity were the highest. Moreover, the maximum photosynthetic rate and photosynthetic capacity of $P$. australis in all five habitats had the same trend of variation, and the trend was consistent with that of Vcmax and Jmax. Overall, our results suggest that study of Vcmax and Jmax is beneficial for exploring the photosynthetic adaptation strategies to harsh environmental changes, such as water shortages in saline-alkaline wetlands, and in other areas facing the same problems in the world. However, if combined with the chlorophyll fluorescence parameters, i.e., the characteristics of the light reaction part of photosynthesis, the variation in photosynthetic capacity can be explained more comprehensively. Hence, the specific photosynthetic process of P. australis deserves further research.

Author Contributions: Conceptualization, S.A.; methodology, S.A. and X.L. (Xiaoyu Li); software, S.A. and P.Q.; validation, B.W. and X.L. (Xiaoyu Li); formal analysis, S.A.; investigation, S.A.; resources, X.L. (Xingtu Liu); data curation, S.A. and X.L. (Xiaoyu Li); writing-original draft preparation, S.A.; writing-review and editing, X.L. (Xingtu Liu), X.L. (Xiaoyu Li), P.Q. and K.Z.; visualization, S.A.; supervision, P.Q. and K.Z.; project administration, B.W. and X.L. (Xiaoyu Li); funding acquisition, X.L. (Xingtu Liu). All authors have read and agreed to the published version of the manuscript.

Funding: This research was funded by the National Natural Science Foundation of China (41971140 and 41771550), the National Key R\&D Program of China (2016YFC05004), the Science Foundation for Excellent Youth Scholars of Jilin Province (20180520097JH), and the Science and Technology Cooperation Foundation of Jilin Province and CAS (2017SYHZ0011).

Acknowledgments: We thank MDPI for its linguistic assistance during the preparation of this manuscript. We thank the teachers and students in the Key Laboratory of Wetland Ecology and Environment of Northeast Institute of Geography and Agroecology of Chinese Academy of Sciences, for their help during field work. We also thank the editors for their support in the processing of the article.

Conflicts of Interest: The authors declare no conflict of interest.

\section{References}

1. Gabler, C.A.; Osland, M.J.; Grace, J.B.; Stagg, C.L.; Day, R.H.; Hartley, S.B.; Enwright, N.M.; From, A.S.; McCoy, M.L.; McLeod, J.L. Macroclimatic change expected to transform coastal wetland ecosystems this century. Nat. Clim. Chang. 2017, 7, 142-147. [CrossRef]

2. Chen, Y.C.; Shih, C.H. Sustainable Management of Coastal Wetlands in Taiwan: A Review for Invasion, Conservation, and Removal of Mangroves. Sustainability 2019, 11, 4305. [CrossRef]

3. Willson, K.G.; Perantoni, A.N.; Berry, Z.C.; Eicholtz, M.I.; Tamukong, Y.B.; Yarwood, S.A.; Baldwin, A.H. Title: Influences of reduced iron and magnesium on growth and photosynthetic performance of Phragmites australis subsp americanus (North American common reed). Aquat. Bot. 2017, 137, 30-38. [CrossRef]

4. Zhou, J.; Xiang, J.; Wang, L.; Zhong, G.; Zhu, G.; Liu, C.; Huang, M.; Feng, W.; Li, Q.; Xue, D.; et al. The Impacts of Groundwater Chemistry on Wetland Vegetation Distribution in the Northern Qinghai-Tibet Plateau. Sustainability 2019, 11, 5022. [CrossRef]

5. Yin, X.L.; Zhang, J.; Hu, Z.; Xie, H.J.; Guo, W.S.; Wang, Q.S.; Ngo, H.H.; Liang, S.; Lu, S.Y.; Wu, W.Z. Effect of photosynthetically elevated $\mathrm{pH}$ on performance of surface flow-constructed wetland planted with Phragmites australis. Environ. Sci. Pollut. Res. 2016, 23, 15524-15531. [CrossRef] 
6. Sun, X.L.; Xu, Y.; Zhang, Q.Q.; Li, X.Z.; Yan, Z.Z. Combined effect of water inundation and heavy metals on the photosynthesis and physiology of Spartina alterniflora. Ecotoxicol. Environ. Saf. 2018, 153, 248-258. [CrossRef]

7. Thornley, J.H.M. Dynamic model of leaf photosynthesis with acclimation to light and nitrogen. Ann. Bot. 1998, 81, 421-430. [CrossRef]

8. Fang, L.; Zhang, S.; Zhang, G.; Liu, X.; Xia, X.; Zhang, S.; Xing, W.; Fang, X. Application of Five Light-Response Models in the Photosynthesis of Populus x Euramericana cv. 'Zhonglin46' Leaves. Appl. Biochem. Biotechnol. 2015, 176, 86-100. [CrossRef]

9. Waring, E.F.; Maricle, B.R. Photosynthetic variation and carbon isotope discrimination in invasive wetland grasses in response to flooding. Environ. Exp. Bot. 2012, 77, 77-86. [CrossRef]

10. Li, S.H.; Ge, Z.M.; Xie, L.N.; Chen, W.; Yuan, L.; Wang, D.Q.; Li, X.Z.; Zhang, L.Q. Ecophysiological response of native and exotic salt marsh vegetation to waterlogging and salinity: Implications for the effects of sea-level rise. Sci. Rep. 2018, 8, 2441. [CrossRef]

11. Xu, J.T.; Zhang, J.A.; Xie, H.J.; Li, C.; Bao, N.; Zhang, C.L.; Shi, Q.Q. Physiological responses of Phragmites australis to wastewater with different chemical oxygen demands. Ecol. Eng. 2010, 36, 1341-1347. [CrossRef]

12. Han, J.Q.; Zhou, Y.M.; Li, D.D.; Zhai, G.Q. Effects of Short-Term High-Salt Stresses on Photosynthetic Characteristics, Activities of Protective Enzyme and Copper Uptake of Acorus Calamus in Microcosm Submerged Wetlands. Fresenius Environ. Bull. 2018, 27, 982-988.

13. Zhang, G.X.; Deng, C.N. Gas exchange and chlorophyll fluorescence of salinity-alkalinity stressed Phragmites australis seedlings. J. Food Agric. Environ. 2012, 10, 880-884.

14. Zhang, C.; Kellomäki, S.; Zhong, Q.; Wang, K.; Gong, J.; Qiao, Y.; Zhou, X.; Gao, W. Seasonal biomass allocation in a boreal perennial grass (Phalaris arundinacea L.) under elevated temperature and $\mathrm{CO}_{2}$ with varying water regimes. Plant Growth Regul. 2014, 74, 153-164. [CrossRef]

15. Yu, W.Y.; Ji, R.P.; Jia, Q.Y.; Feng, R.; Wu, J.W.; Zhang, Y.S. Vertical distribution characteristics of photosynthetic parameters for Phragmites australis in Liaohe River Delta wetland, China. J. Freshw. Ecol. 2017, 32, 557-573. [CrossRef]

16. Li, X.Y.; Li, X.J.; Lin, J.X.; Wen, B.L. Effects of sub-soiling and fertilization on growth restoration of Phragmites australis population in saline marsh of northeast China. Fresenius Environ. Bull. 2017, 26, 1453-1460.

17. Ye, Z.P. A new model for relationship between irradiance and the rate of photosynthesis in Oryza sativa. Photosynthetica 2007, 45, 637-640. [CrossRef]

18. Flexas, J.; Bota, J.; Escalona, J.M.; Sampol, B.; Medrano, H. Effects of drought on photosynthesis in grapevines under field conditions: An evaluation of stomatal and mesophyll limitations. Funct. Plant Biol. 2002, 29, 461-471. [CrossRef]

19. Vona, V.; Rigano, V.D.; Andreoli, C.; Lobosco, O.; Caiazzo, M.; Martello, A.; Carfagna, S.; Salbitani, G.; Rigano, C. Comparative analysis of photosynthetic and respiratory parameters in the psychrophilic unicellular green alga Koliella antarctica, cultured in indoor and outdoor photo-bioreactors. Physiol. Mol. Biol. Plants 2018, 24, 1139-1146. [CrossRef]

20. Mahmud, K.; Medlyn, B.E.; Duursma, R.A.; Campany, C.; De Kauwe, M.G. Inferring the effects of sink strength on plant carbon balance processes from experimental measurements. Biogeosciences 2018, 15, 4003-4018. [CrossRef]

21. Tho, B.T.; Lambertini, C.; Eller, F.; Brix, H.; Sorrell, B.K. Ammonium and nitrate are both suitable inorganic nitrogen forms for the highly productive wetland grass Arundo donax, a candidate species for wetland paludiculture. Ecol. Eng. 2017, 105, 379-386. [CrossRef]

22. Zhang, Z.; Rengel, Z.; Meney, K. Interactive effects of $\mathrm{N}$ and $\mathrm{P}$ on growth but not on resource allocation of Canna indica in wetland microcosms. Aquat. Bot. 2008, 89, 317-323. [CrossRef]

23. Holaday, A.S.; Schwilk, D.W.; Waring, E.F.; Guvvala, H.; Griffin, C.M.; Lewis, O.M. Plasticity of nitrogen allocation in the leaves of the invasive wetland grass, Phalaris arundinacea and co-occurring Carex species determines the photosynthetic sensitivity to nitrogen availability. J. Plant Physiol. 2015, 177, 20-29. [CrossRef]

24. Holmes, G.D.; Hall, N.E.; Gendall, A.R.; Boon, P.I.; James, E.A. Using Transcriptomics to Identify Differential Gene Expression in Response to Salinity among Australian Phragmites australis Clones. Front. Plant Sci. 2016, 7, 432. [CrossRef] [PubMed] 
25. Li, L.; Qiu, S.J.; Chen, Y.P.; Xu, X.L.; Zhao, X.M.; Christie, P.; Xu, M.G. Allocation of photosynthestically-fixed carbon in plant and soil during growth of reed (Phragmites australis) in two saline soils. Plant Soil 2016, 404, 277-291. [CrossRef]

26. Lessmann, J.M.; Brix, H.; Bauer, V.; Clevering, O.A.; Comin, F.A. Effect of climatic gradients on the photosynthetic responses of four Phragmites australis populations. Aquat. Bot. 2001, 69, 109-126. [CrossRef]

27. Shoukat, E.; Abideen, Z.; Ahmed, M.Z.; Gulzar, S.; Nielsen, B.L. Changes in growth and photosynthesis linked with intensity and duration of salinity in Phragmites karka. Environ. Exp. Bot. 2019, 162, 504-514. [CrossRef]

28. Guo, X.; Yu, T.; Li, M.; Guo, W. The effects of salt and rainfall pattern on morphological and photosynthetic characteristics of Phragmites australis (Poaceae). J. Torrey Bot. Soc. 2018, 145, 212-224. [CrossRef]

29. Abideen, Z.; Qasim, M.; Hussain, T.; Rasheed, A.; Gul, B.; Koyro, H.; Ansari, R.; Khan, M.A. Salinity improves growth, photosynthesis and bioenergy characteristics of Phragmites karka. Crop Pasture Sci. 2018, 69, 944-953. [CrossRef]

30. Gu, L.; Pallardy, S.G.; Tu, K.; Law, B.E.; Wullschleger, S.D. Reliable estimation of biochemical parameters from C-3 leaf photosynthesis-intercellular carbon dioxide response curves. Plant Cell Environ. 2010, 33, 1852-1874. [CrossRef]

31. Sharkey, T.D.; Bernacchi, C.J.; Farquhar, G.D.; Singsaas, E.L. Fitting photosynthetic carbon dioxide response curves for C-3 leaves. Plant Cell Environ. 2007, 30, 1035-1040. [CrossRef] [PubMed]

32. Waring, E.F.; Holaday, A.S. High growth temperatures and high soil nitrogen do not alter differences in $\mathrm{CO}_{2}$ assimilation between invasive Phalaris arundinacea (reed canarygrass) and Carex stricta (tussock sedge). Am. J. Bot. 2017, 104, 999-1007. [CrossRef] [PubMed]

33. Nackley, L.L.; Kim, S.H. A salt on the bioenergy and biological invasions debate: Salinity tolerance of the invasive biomass feedstock Arundo donax. Glob. Chang. Biol. Bioenergy 2015, 7, 752-762. [CrossRef]

34. Guo, W.Y.; Lambertini, C.; Guo, X.; Li, X.Z.; Eller, F.; Brix, H. Phenotypic traits of the Mediterranean Phragmites australis M1 lineage: Differences between the native and introduced ranges. Biol. Invasions 2016, 18, 2551-2561. [CrossRef]

35. Zhu, X.Y.; Wang, S.M.; Zhang, C.L. Composition and characteristic differences in photosynthetic membranes of two ecotypes of reed (Phragmites communis L.) from different habitats. Photosynthetica 2003, 41, 97-104. [CrossRef]

36. Zhu, X.Y.; Chen, G.C.; Zhang, C.L. Photosynthetic electron transport, photophosphorylation, and antioxidants in two ecotypes of reed (Phragmites communis Trin.) from different habitats. Photosynthetica 2001, 39, 183-189. [CrossRef]

37. Nada, R.M.; Khedr, A.H.A.; Serag, M.S.; El-Nagar, N.A. Growth, photosynthesis and stress-inducible genes of Phragmites australis (Cav.) Trin. ex Steudel from different habitats. Aquat. Bot. 2015, 124, 54-62. [CrossRef]

38. Li, X.Y.; Wen, B.L.; Yang, F.; Hartley, A.; Li, X.J. Effects of alternate flooding-drought conditions on degenerated Phragmites australis salt marsh in Northeast China. Restor. Ecol. 2017, 25, 810-819. [CrossRef]

39. Wen, B.L.; Li, X.Y.; Yang, F.; Lu, X.R.; Li, X.J.; Yang, F.Y. Growth and physiology responses of Phragmites australis to combined drought-flooding condition in inland saline-alkaline marsh, Northeast China. Ecol. Eng. 2017, 108, 234-239. [CrossRef]

40. Mashaly, I.A.; El-Habashy, I.E.; El-Halawany, E.F.; Omar, G. Habitat and plant communities in the Nile Delta of Egypt. II. Irrigation and drainage canal bank habitat. Pak. J. Biol. Sci. 2009, 12, 885-895. [CrossRef] [PubMed]

41. Marcaccio, J.V.; Chow-Fraser, P. Mapping Options to Track Invasive Phragmites australis in the Great Lakes Basin in Canada. In Water Resources and Wetlands; Gastescu, P., Bretcan, P., Eds.; Romanian Limnogeographical Assoc: Targoviste, Romania, 2016; pp. 75-82.

42. Tuominen, J.; Lipping, T. Spectral Characteristics of Common Reed Beds: Studies on Spatial and Temporal Variability. Remote Sens. 2016, 8, 181. [CrossRef]

43. Luo, J.; Ma, R.; Feng, H.; Li, X. Estimating the Total Nitrogen Concentration of Reed Canopy with Hyperspectral Measurements Considering a Non-Uniform Vertical Nitrogen Distribution. Remote Sens. 2016, 8, 789. [CrossRef]

44. Thevs, N.; Beckmann, V.; Akimalieva, A.; Köbbing, J.F.; Nurtazin, S.; Hirschelmann, S.; Piechottka, T.; Salmurzauli, R.; Baibagysov, A. Assessment of ecosystem services of the wetlands in the Ili River Delta, Kazakhstan. Environ. Earth Sci. 2017, 76, 30. [CrossRef] 
45. Zhu, L.; Chen, Z.; Wang, J.; Ding, J.; Yu, Y.; Li, J.; Xiao, N.; Jiang, L.; Zheng, Y.; Rimmington, G.M. Monitoring plant response to phenanthrene using the red edge of canopy hyperspectral reflectance. Mar. Pollut. Bull. 2014, 86, 332-341. [CrossRef]

46. Zheng, X.M.; Song, P.L.; Li, Y.Y.; Zhang, K.Y.; Zhang, H.J.; Liu, L.; Huang, J.F. Monitoring Locusta migratoria manilensis damage using ground level hyperspectral data. In Proceedings of the 2019 8th International Conference on Agro-Geoinformatics, Istanbul, Turkey, 16-19 July 2019.

47. Yuan, Q.; Alpert, P.; An, J.; Gao, J.; Han, G.; Yu, F. Clonal integration in Phagmites australis mitigates effects of oil pollution on greenhouse gas emissions in a coastal wetland. Sci. Total Environ. 2020, 739, 140007. [CrossRef]

48. Song, U. Improvement of soil properties and plant responses by compost generated from biomass of phytoremediation plant. Environ. Eng. Res. 2020, 25, 638-644. [CrossRef]

49. Cronin, J.T.; Johnston, J.; Diaz, R. Multiple Potential Stressors and Dieback of Phragmites australis in the Mississippi River Delta, USA: Implications for Restoration. Wetlands 2020. [CrossRef]

50. Van Tran, G.; Unpaprom, Y.; Ramaraj, R. Methane productivity evaluation of an invasive wetland plant, common reed. Biomass Convers. Biorefinery 2020, 10, 689-695. [CrossRef]

51. Xia, S.; Song, Z.; Van Zwieten, L.; Guo, L.; Yu, C.; Hartley, I.P.; Wang, H. Silicon accumulation controls carbon cycle in wetlands through modifying nutrients stoichiometry and lignin synthesis of Phragmites australis. Environ. Exp. Bot. 2020, 175, 104058. [CrossRef]

52. Liu, Y.; Ding, Z.; Bachofen, C.; Lou, Y.; Jiang, M.; Tang, X.; Lu, X.; Buchmann, N. The effect of saline-alkaline and water stresses on water use efficiency and standing biomass of Phragmites australis and Bolboschoenus planiculmis. Sci. Total Environ. 2018, 644, 207-216. [CrossRef]

53. Leverenz, J.W.; Jarvis, P.G. Photosynthesis in Sitka Spruce. VIII. The Effects of Light Flux Density and Direction on the Rate of Net Photosynthesis and the Stomatal Conductance of Needles. J. Appl. Ecol. 1979, 16, 919-932. [CrossRef]

54. Marshall, B.; Biscoe, P.V. A Model for C3 Leaves Describing the Dependence of Net Photosynthesis on Irradiance. J. Exp. Bot. 1980, 31, 29-39. [CrossRef]

55. Medlyn, B.E.; Dreyer, E.; Ellsworth, D.; Forstreuter, M.; Harley, P.C.; Kirschbaum, M.U.F.; Le Roux, X.; Montpied, P.; Strassemeyer, J.; Walcroft, A.; et al. Temperature response of parameters of a biochemically based model of photosynthesis. II. A review of experimental data. Plant Cell Environ. 2002, 25, 1167-1179. [CrossRef]

56. Farquhar, G.D.; Caemmerer, S.V.; Berry, J.A. A biochemical model of photosynthetic $\mathrm{CO}_{2}$ assimilation in leaves of C3 species. Planta 1980, 149, 78-90. [CrossRef] [PubMed]

57. Duursma, R.A. Plantecophys-An R Package for Analysing and Modelling Leaf Gas Exchange Data. PLoS ONE 2015, 10, e0143346. [CrossRef] [PubMed]

(C) 2020 by the authors. Licensee MDPI, Basel, Switzerland. This article is an open access article distributed under the terms and conditions of the Creative Commons Attribution (CC BY) license (http://creativecommons.org/licenses/by/4.0/). 